\title{
Hodnota práce u české veřejnosti v letech 1991-2008'
}

\author{
Value of Work among Czech Publics from 1991 to 2008 \\ Petr Mareš, Tomáš Katrňák
}

\begin{abstract}
The article deals with the job value. Authors analyze the European Values Study data (representative surveys for years 1991, 1999 and 2008). Authors focus on the change of job value from 1991, when the Czech Republic joined the European countries analyzed under EVS. Based on classic as well as latent cluster analysis the authors deal with the segmentation of Czech population by job value comparing to other life values (leisure time, friends, religion and politics). Results show, that Czech public in respect to job value neither to the concept of job is not homogenized. In both cases the analysis of job identified three clusters that are differentiated by respondent's education and age.
\end{abstract}

KEY WORDS job characteristics and their value, paid work, work ethics, work ethos, the absolute value of labor, the relative value of work

\section{Úvod}

Tato stat' využívá data sesbíraná v roce 2008 v rámci výzkumu European Values Study (dále jen EVS, blíže k tomuto výzkumu viz editorial tohoto čísla) k zodpovězení základní otázky, jakou hodnotu má v populaci České republiky práce? At’ již sama o sobě (absolutní hodnota práce) nebo ve srovnání s dalšimi sférami lidského života (relativní hodnota práce), které výzkum sleduje a jimiž jsou rodina a volný čas. Klademe si též otázku, jakou důležitost lidé v České republice přisuzuji jednotlivým charakteristikám své konkrétní pracovní činnosti, a otázku o míre jejich spokojenosti se svou prací. A to vše s ohledem na možnou diferenciaci respondentů, založenou na jejich základních demografických a sociálních charakteristikách, jako jsou věk a vzdělání.

Vzhledem k tomu, že v roce 2008 šlo již o třetí vlnu výzkumu EVS, která byla realizována v populaci České republiky (1991, 1999 a 2008), můžeme si položit i otázku, zda došlo v posuzování hodnoty práce a hodnoty jednotlivých charakteristik práce po roce 1989 k nějakému vývoji. Obecně se totiž předpokládá, že po roce 1989 došlo v České republice, stejně jako v dalších postsocialistických zemích, k významným nejen politickým,

Sociální studia. Fakulta sociálních studií Masarykovy univerzity, 4/2010. S. 121-143. ISSN 1214-813X.

1 Studie vznikla s podporou Grantové agentury ČR - projekt „Hodnotové proměny v ČR 1991-2008 v evropském kontextu“ (GA403/08/0999) a s podporou Ministerstva školství, mládeže a tělovýchovy - výzkumný záměr „Reprodukce a integrace společnosti“ (MSM0021622408). 
ale i ekonomickým a sociální změnám, které jejich obyvatelstvo přibližují k hodnotovým orientacím, charakteristickým pro ty evropské země, které se nikdy socialistickými nesta$\mathrm{ly}^{2} \mathrm{~S}$ ohledem na data, která máme $\mathrm{k}$ dispozici, si můžeme v této souvislosti položit otázku, nakolik to platí v prŕípadě hodnoty (placené) práce. Můžeme se též ptát, do jaké míry nás tyto změny posouvají k hodnotové orientaci zemí západní Evropy, respektive zda se hodnocení práce v populaci České republiky liši od jejího hodnoceni v těchto zemích, ale i v ostatních postkomunistických zemích (i když se primárně zabýváme situací v České republice a klasická komparativní analýza není naším cílem).

Je přitom třeba poznamenat, že hovoříme-li dnes o práci, máme co do činění s konceptem časově i prostorově určeným. Na rozdíl od většiny předmoderních společností, v nichž práce nebyla odlišitelná od ostatních aktivit, a které proto neměly pro práci žádné zvláštní označení (Giddens 1994: 176), jedná se dnes o práci placenou (výdělečnou) a vykonávanou v zaměstnaneckém poměru nebo jako živnost či jako svobodné povolání. K ní se také vztahují data, která používáme.

\section{Hodnota práce v současné společnosti}

Hodnota placené práce dnes spočívá zejména $\mathrm{v}$ tom, že práce stále představuje dominantní nástroj integrace do společnosti. Jedinci se v moderní společnosti stávají jejími plnoprávnými členy (svou integrací do sociální třídy) právě prostřednictvím placené práce (Gorz 1999: 55-56) a z pracovního výkonu je odvozena nejen jejich životní úroveň, ale i řada důležitých práv, jimž se ve společnosti těší. „Industriální společnost je tak i mimo sféru práce skrz naskrz společností výdělečné práce“ (Beck 2004: 223), která „představuje osu života člověka a spolu s rodinou tvoří bipolární systém souřadnic, $v$ němž je jeho život $v$ této epoše zakotven“ (Beck 2004: 221). Jakožto proces i jakožto instituce dovoluje placená práce jedincům překonat jejich individuální rámec a spojuje je se sociálním, ekonomickým a politickým světem (Ardichvilia Kuchinke 2009). Jako výkon profese a zaměstnáni práce situuje člověka na pracovním trhu (specificky) i v sociální struktuře společnosti (obecně) a spoluurčuje tak jeho př́ijem, prestiž, sociální pole, v němž se pohybuje, i jeho habitus (Bourdieu 1999) a životní styl, ale i jeho identitu a sebevědomí. Jakožto činnost je pak práce pro jedince prostorem (i limitujícím faktorem) jeho seberealizace a významným zdrojem vnitřního životního (ne)uspokojení, takže je pro většinu osob úzce spjata s jejich koncepcí sebe sama (Watson 2009).

Je tomu tak stále, i když Inglehart $(1977,1999,2008)$ upozornil na posun populací průmyslově rozvinutých zemí od materialistických k postmaterialistickým hodnotovým

2 Podle dnes již klasické Dahrendorfovy metaforické předpovědi z roku 1991 měla mít každá z nich jinou dynamiku. Zatímco změna politická (zákonů) mohla být, podle Dahrendorfa, provedena do šesti měsíců, změna ekonomických systémů postkomunistických zemí si měla vyžádat šest let, ale kulturní změna, změna hodnot a postojů lidí měla trvat šedesát let (Dahrendorf 1991a). Analogicky fakt, že intergenerační změny hodnot postupují velmi pomalu, připomíná i Inglehart (2008: 131). Je tedy otázkou, zda je našich dvacet let od roku 1989 na výraznější změny v hodnotových orientacích dostatečně dlouhou dobou. 
orientacím. Vztaženo k práci, jde zejména o míru, v níž jsou na jedné straně akcentovány př́ijem a stabilita pracovního místa jako odpověd' na potřeby fyzického a ekonomického bezpečí (charakteristické spíše pro starší generaci) a na druhé straně společensky užitečná a ceněná práce jako uspokojení potřeb seberealizačních a sociálních (charakteristických spíše pro mladší generaci). Halman (1996) na datech z EVS analogicky dokládá, že v dříve modernizovaných zemích severozápadní Evropy existuje, na rozdíl od později modernizovaných evropských zemí, tendence $\mathrm{k}$ posunu od důrazu na instrumentální hodnotu práce (př́ijem, jistota místa) k důrazu na její expresivní hodnotu (kreativita, autonomie, seberealizace a osobnostní rozvoj).

Řada autorů ovšem poukazuje na to, že nejde jen o tento posun, ale i o to (a zejména o to), že tak, jak roste schopnost společnosti zajistit ekonomický růst, aniž by $\mathrm{k}$ tomu bylo zapotřebí plné zaměstnanosti, a jak se tímto placená práce „mění $\mathrm{z}$ břemene $\mathrm{v}$ privilegium“ (Dahrendorf 1991b: 225), ${ }^{3}$ klesá hodnota práce jako takové. Stále častěji se hovoří o tom, že strukturální změny v povaze placené práce a v jejím výkonu (např́klad Sennett 1998, 2006 či Castel 2003) nastolují rostoucí potřebu redefinovat její význam. ${ }^{4}$ Pokles hodnoty práce $\mathrm{v}$ životě jedinců je přitom spojován nejen $\mathrm{s}$ úbytkem pracovních príležitostí a s poklesem míry závislosti lidí na př́ijmech z placené práce, ale i s obecnými posuny v hodnotách či životním stylu současné populace. V Inglehartem popsaném posunu od moderních k postmoderním hodnotám (Inglehart 1977, 2008) podle řady autorů slábne nejen instrumentální funkce placené práce (př́ijem z ní lze do určité míry či na určitou dobu nahradit jiným typem př́ijmu), ale slábne i její seberealizační funkce. Mnoho lidí dnes svou seberealizaci hledá spíše ve volném čase či v rodinném životě než v práci. Bauman (1998: 23) v tomto ohledu konstatoval, že dnes lidé svoji identitu odvozují více ze spotřeby než z práce, a metaforicky $\mathrm{v}$ této souvislosti hovoří o přechodu od etiky práce $\mathrm{k}$ estetice spotřeby. Zmiňovaný trend poklesu celkové hodnoty práce pro jedince ovšem není tak jednoznačný. Jak ukazuje například Jaufmann (2000) na datech z Německa, v současnosti zde hodnota práce naopak stoupá, a to více $\mathrm{v}$ jeho východní než $\mathrm{v}$ západní části. Dochází $\mathrm{k}$ tomu právě $\mathrm{v}$ důsledku růstu nezaměstnanosti a zvyšování nejistoty pracovních míst, které z placené práce dělají vzácné zboží. Celková hodnota práce tak přece jen i dnes roste, a to skrze rưst její instrumentální hodnoty, a to více tam, kde jsou na ní lidé existenčně více závislí. To je, jak se domnívají Davoine a Méda (2009: 16) s odvoláním se na European Values Study (EVS), International Social

3 Na tuto tendenci jako jeden z prvních upozornil již v 30. letech minulého století Keynes (1931). V 60. letech minulého století tato prognóza nabyla optimistických úvah o př́íchodu společnosti volného času (Fourastié 1969). Dnes ale vynořivší se otázky typu „Jak vést smysluplný život i v prípadě, že nenajdu pracovní misto?" nebo „Je svoboda a demokracie možná i bez plné zaměstnanosti?“ či „, Jak se z člověka bez placené práce stane sebevědomý občan?“ (Beck 2006) již tak optimisticky neznějí. Píše-li Gorz (1999: 73) o přicházející společnosti, v níž pracovní čas přestane být dominantním sociálním časem, je to svým obsahem jiné tvrzení, než zmíněný projekt společnosti volného času z 60 . let minulého století.

4 Namátkou lze v této souvislosti uvést jména autorů, jako jsou Aronowitz and DiFazio 1994; Casey 1995, 2000; Delors 1992, Deranty 2008; Gorz 1999; Rifkin 1995; Dahrendorf 1991b; Beck 1998, 2000, 2004; Bauman 1995, 1998, 2002; Bell 1999; Castel 2003; Lash a Urry 1987. Dva posledně jmenovaní hovoří v této souvislosti o konci organizovaného kapitalismu. 
Survey Programme (ISSP) a European Social Survey (ESS), důvodem toho, že v zemích střední a východní, ale i jižní Evropy si většina osob, na rozdíl od obyvatel Velké Británie, Belgie, Švédska či Francie, nepřeje, aby práce v jejich životě ztrácela na významu.

\section{Absolutní a relativní hodnota práce}

Jak upozorňují Sweet a Meiksins (2008), na práci lze nahližžet jako na sociální instituci, jež podléhá sociálním či kulturním normám a má hodnotu sama o sobě (absolutní hodnota práce), stejně tak jako na instituci, která podléhá individuálním očekáváním a jejíž hodnota je poměřována ve vztahu k jiným sférám života jedince, jako jsou rodina, náboženství, volný čas, sociální sítě a další (relativní hodnota práce). ${ }^{5}$

Co se týče absolutni hodnoty práce, toto pojetí činí z práce centrální bod života jedince a staví ji před jedince jako jeho morální povinnost (viz již Max Weber) at' již vůči bohu, nebo společnosti, popř́padě i vůči rodině. Hodnota práce zde není odvozována z její instrumentální funkce, ale ze samotného jejího výkonu, a to bez ohledu na její obsah či charakter (etika práce či pracovní étos). Pracovat, stejně jako žít jen z výtěžku placené práce se považuje za hodnotu i normu. Př́íprava $\mathrm{k}$ placené práci vštěpováním předpokladů jejího efektivního výkonu již ve fázi socializace - at' již jde o ukázňování těla a ducha (Foucault 2000), či o osvojování hodnot a návyků potřebných v hromadné výrobě (Illich 2001) - představují v industriální společnosti silný indoktrinační proud. Práce je proto také spojována se sankcemi. Pozitivními: Na práci je vázán nejen př́ijem jedince, ale i soubor jeho oprávnění ve vztahu k sociálnímu státu. Negativními: Ti, kdo jsou schopni pracovat, ale práci se (z důvodů, jež v dané společnosti nejsou legitimními) vyhýbají, jsou v různé míře považováni za asociály, jsou vylučováni z různých sociálních výhod, či dokonce ostrakizováni. ${ }^{6}$

$\mathrm{S}$ relativni hodnotou práce máme co do činění tehdy, když je hodnota sféry práce porovnávána s hodnotou jiných životních sfér, $v$ našem př́padě $\mathrm{s}$ hodnotou rodinného života a s hodnotou volného času. Rostoucí důraz, který je na rodinu a volný čas v lidském životě kladen, vede $\mathrm{v}$ současné době $\mathrm{k}$ tomu, že se dostávají v mnoha ohledech se sférou práce do konfliktu. Greenhaus a Beutell (1985) považují za předměty tohoto konfliktu zejména nedostatek času jedinců pro jejich rodinný život a volný čas v důsledku jejich pracovní zaangažovanosti a nesoulad mezi očekáváními, která jsou na jedince kladena současně v zaměstnání a v rodině. Zmiňují však také vliv stresu a konfliktů, jimž je člověk v práci vystaven, na jeho mimopracovní život. Zajištění a udržení rovnováhy mezi pracovním a rodinným životem, minimalizace konfliktů mezi nimi a posilování uspokojení dosahovaného v práci jsou dnes považovány za podmínku efektivity fungování jedince v rodině (Frone 2003).

5 Pracovní hodnoty bývají považovány za projekci obecných hodnot do specifické sféry práce a předpokládá se, že v moderní průmyslové společnosti zaujímají v hodnotovém systému jedinců i společnosti klíčovou roli. Takto např́klad operacionalizuje centralitu práce v životě jedinců mezinárodní výzkumný program „MOW - The Meaning of Working“, založený v roce 1978 s cílem identifikovat hodnoty, postoje a očekávání, které členové industrializovaných společností spojují s prací a zaměstnáním.

6 Například před rokem 1990 existovaly v tehdejším Československu právní normy, umožňující trestat nepracující jedince vězením za tzv. př̌žživnictví. 
A vice versa, uspokojení dosahované člověkem v rodinném životě je považováno za podmínku efektivity výkonu jeho zaměstnání (Voydanoff 2005). Snaha přijímat opatření, která usilují o odstranění či alespoň zmírnění konfliktů mezi zaměstnáním a rodinou, je proto stále patrnější i v podnikatelském prostředí (blíže k tomu např́iklad Carlson, Grzywacz a Zivnuska 2009, v české literatuře např́iklad Mareš 2006, Sirovátka 2006 či Valentová 2006).

\section{Jednotlivé charakteristiky práce a jejich hodnota}

Jak konstatují Sharabi a Harpaz (2009), představuje hodnota přisuzovaná práci složitý komplex, který má pro většinu lidí řadu významových vrstev. Práce jim (a jejich rodinám) zajišt’uje základní životní potřeby, ale uspokojuje i jejich potřebu učit se, rozvíjet svou osobnost, konstruovat realitu či dosahovat cílů a další. V neposlední řadě pak dává práce jejich životům význam jakožto součásti života širší společnosti. Z tohoto hlediska je hodnota práce pro jedince dána hodnotou, kterou přisuzuje jednotlivým charakteristikám práce vykonávané $\mathrm{v}$ jeho zaměstnání. Tato hodnota může být u různých charakteristik práce pro různé jedince odlišná a tito mohou být také $\mathrm{s}$ povahou jednotlivých charakteristik své práce v různé míře spokojeni či nespokojeni. Například podle zjištění longitudinálního projektu The Meaning of Working považují jedinci za nejdůležitější charakteristiky své práce př́jem, status a prestiž, kontakty navazované v práci/zaměstnání, prŕiležitost být užitečný pro společnost, uspokojení vlastních osobních zájmů skrze pracovní činnost a absorpci času prací (Harpaz a Fu 2002).

Existuje řada pokusů charakteristiky práce (někdy se hovoří o cílech) kategorizovat, a to jak teoreticky, tak i na základě empirických dat, stejně jako se o to snažíme i my. ${ }^{7}$ Zmíněný výzkum The Meaning of Working (MOW - International Research Team 1987) rozlišuje mezi instrumentálními (prŕijem), expresivními (zajímavá práce, autonomie při jejím výkonu), osobnost rozvíjejicími (př́ležitost $\mathrm{k}$ růstu znalostí, dovedností, schopností a kvalifikace) a určitý komfort poskytujícími (vyhovující pracovní doba a podmínky výkonu práce) cíli práce. ${ }^{8}$ Jiní autoři rozlišují mezi vnitřni pracovní orientaci na práci samu o sobě, poskytující př́ležitost pro rozvoj a sebevyjádření jedince, jeho dovedností a zájmů, a vnější pracovní orientací, kdy práce není smyslem a cílem sama o sobě, ale je jen prostředkem k dosažení cílů, ležících mimo její sféru (Tarnai a kol. 1995: 140). Obdobně Halman a Müller (2006) rozlišují vnitřní (intrinsic) charakteristiky práce spojené př́mo s pracovním procesem (zajímavost práce,

7 V české sociologii se pokusil o intuitivní a na datech testovanou kategorizaci charakteristik práce v 70. letech minulého století Možný (1974), i když, na rozdíl od European Values Study, se neptal na důležitost jednotlivých charakteristik práce, ale na spokojenost s nimi (bliže také Mareš 2001 či Mareš a Bánovcová 2002).

8 Do značné míry to odpovídá kategorizaci, kterou navrhli již koncem 60. let Goldthrope a kol. (1968). Obdobně pak rozlišuje Zanders (1995) mezi charakteristikami podporujícími osobni rozvoj (možnost uplatnit své schopnosti, iniciativu či odpovědnost, možnost dosáhnout výsledků, zajímavost práce), charakteristikami poskytujícimi určitý komfort výkonu práce (nepracovat pod tlakem, mít respektovanou práci, výhodnou pracovní dobu a dlouhou dovolenou), charakteristikami představujícimi materiální podmínky práce (dobrý plat, pracovní prostředí či jistota pracovního místa) a jejími dalšími, dále nediferencovanými charakteristikami (spolupracovníci, kariéra, užitečnost pro společnost a další). 
př́ležitost uplatnit schopnosti, být kreativní apod.) a vnější (extrinsic) charakteristiky práce spojené s jejími výsledky a konsekvencemi (př́ijem, status apod.). Tvrdí přitom, že ve společnostech s větší mírou př́ijmových nerovností kladou lidé větší důraz na materiální aspekty práce (extrinsic orientation), zatímco ve společnostech s menší mírou př́jmových nerovností ho kladou na vnitřní aspekty práce (intrinsic orientation).

\section{Diferenciace a změna}

Je ovšem otázkou, nakolik je hodnota práce i jednotlivých charakteristik práce univerzálně platná (alespoň v industrializovaných zemích) a nakolik variuje v závislosti na čase, ale i v závislosti na fyzickém či kulturním, respektive sociálním prostoru. Kulturní mapa světa, načrtnutá Inglehartem a Welzelem (2005) na základě dat získaných ve World Values Surveys ${ }^{9}$ reflektuje fakt, že základní hodnoty vzájemně korelují a vytváří tak faktory, charakteristické pro určité kultury. Podle autorů se odlišnosti mezi těmito hodnotami projevily zejména ve dvou dimenzích, které vysvětlují 70\% variancí mezi jednotlivými zeměmi (ve faktorové analýze deseti použitých indikátorů). Jde jednak o dimenzi odrážející kontrast mezi společnostmi podle míry významu náboženství v životě jejich obyvatel, jednak o dimenzi odrážející míru změny společnosti z industriální $\mathrm{k}$ post-industriální formě, přinášející polarizaci hodnot spojených s otázkami existenčními a hodnot spojených s možností seberealizace a sebevyjádření.

Různé komparativní studie (Hagenaars, Halman a Moors 2003 či Loek a Müller 2006) ukazují, že také rozdíly v hodnotě práce (a jejích charakteristik) a v úloze, kterou práce hraje v životě společnosti, ale i v životech jedinců (stejně jako rozdíly ve spokojenosti s vlastní prací) v jednotlivých zemích a regionech, jsou kulturně a sociálně podmíněné. Lze je považovat za produkt odlišnosti trajektorií modernizace, individualizace a globalizace daných společností, jež se promítají do povahy pracovních institucí a pracovních trhů těchto zemí či regionů i do povahy a organizace práce na nich. Zmíněný předpoklad (Inglehart 1997), že populace zemí s rozvinutou ekonomikou, vysokou životní úrovní a s ní korespondující úrovní existenčních jistot mají tendenci posouvat se od materiálních k post-materiálním hodnotám, by mohl vysvětlovat, že pokles důležitosti materiálních charakteristik práce (extrinsic) a růst hodnoty práce jako sféry pro seberealizaci, k nimž podle dat EVS v Evropě dochází (de Witte, Halman a Gelissen 2004), neprobíhá ve všech evropských zemích stejnou měrou.

Dekker (2007) konstatuje existenci rozdílů v hodnotě přisuzované práci mezi původními a novými členskými zeměmi Evropské unie, přičemž Česká republika je, podle něho, těmto původním členským zemím blíže než ostatní postkomunistické země (včetně Polska, Mad'arska i Slovenska). Podle Večerníka (2006) je pro původní země EU charakteristický větší důraz kladený zde na zajímavost práce a na nezávislost člověka při jejím výkonu, zatímco $\mathrm{v}$ nových členských zemích je větší důraz kladen na odměnu s prací spojenou. $\mathrm{Na}$ datech ISSP (International Social Survey Program) pak dokladuje, že mezi lety 1999

9 Viz mapa hodnot založená na datech z World Values Surveys (Inglehart and Welzel 2005: 64) dostupná na http://www.worldvaluessurvey.org/wvs/articles/folder_published/article_base_54 
a 2005 došlo v České republice $\mathrm{k}$ důležitému poklesu jak sociální hodnoty práce, tak i její hodnoty jakožto prostoru pro seberealizaci. ${ }^{10}$

Rozdíly ovšem existují i uvnitř regionů a států, kde je hodnota přisuzovaná práci a jejím jednotlivým charakteristikám sociálně podmíněná. Není dána jen individuálními schopnostmi, potřebami a přáními jedinců, ale také jejich místem ve společnosti, indikovaným jejich sociálně-demografickými charakteristikami. Významné jsou zejména čtyři z nich, a to pohlaví, vzdělání, socioekonomický status a věk. Věk je zajímavý již z toho důvodu, že podle některých autorů provedené longitudinální výzkumy (navzdory prognózám o úpadku hodnoty práce) sice potvrzují fakt, že vysoká (absolutní) hodnota práce ve společnosti je v evropské společnosti dlouhodobě stabilní veličinou, ale naznačují změny její hodnoty v průběhu životního cyklu jedinců (Lincoln a Kalleberg 1990, Ruiz-Quintanilla a Wilpert 1991, Mannheim a kol. 1997, Harpaz 1999). Dosvědčují to i data z EVS 1999, zveřejněná v Atlas of European Values, podle nichž je zřejmé, že míra pracovního étosu byla v této vlně výzkumu v evropském průměru vyšší u starší generace. ${ }^{11} \mathrm{~S}$ konstatováním ,pracovat je povinností vioči společnosti" silně souhlasilo $15 \%$ osob ve věku 18-30 let, ale 30\% osob ve věku nad 60 let v součtu silného souhlasu a souhlasu byl tento poměr $52 \%: 79 \%$. V případě výroku ,práce by měla mít vždy prednost, $i$ když to znamená mít méně volného času“ byl tento poměr analogický. Silný souhlas s ním vyjádřilo $11 \%$ respondentů ve věku $18-30$ let, ale $23 \%$ osob ve věku nad 60 let $-\mathrm{v}$ součtu silného souhlasu a souhlasu byl tento poměr 39\%: $63 \%$ (Halman, Luijkx a van Zundert 2005).

\section{Data a jejich analýza}

Data, která budeme analyzovat, pocházejí ze tří vln (v letech 1991, 1999 a 2008) reprezentativního výběrového šetření EVS (European Values Study). Jde o reprezentativní data sbíraná dotazníky v jednotlivých evropských zemích. Omezíme se zde na výběrové soubory České republiky (ve věkovém rozpětí 18-60 let), a to na soubor z roku 2008 a na soubor vzniklý spojením všech tří vln realizovaných v České republice.

\section{Absolutní hodnota práce}

V European Values Study byla absolutní hodnota práce jakožto pracovní étos indikována mírou souhlasu s těmito výroky: (1) Člověk musí mit práci, aby mohl plně rozvinout své vlohy; (2) Je ponižující dostávat penize, aniž by si je člověk musel vydělat; (3) Lidé, kteř́ nepracují, zlenivi; (4) Pracovat je povinností vioči společnosti; (5) Práce by měla mít vždy přednost, $i$ když to znamená mít méně volného času. Takto formulované otázky však byly kladeny jen ve dvou posledních vlnách, údaje za rok 1991 proto bohužel chybí.

10 MOW - The Meaning of Working (http://users.ugent.be/ rclaes/MOW/index.html), ISSP - International Social Survey Programme (http://www.issp.org) a World Values Survey (http://www.worldvaluessurvey.org).

11 Další informace je možné nalézt též na http://www.europeanvaluesstudy.eu/evs/evsatlas.html, respektive http://www.atlasofeuropeanvalues.eu/homepage.php?lang=en 
Tabulka 1: Absolutní hodnota práce: Důležitost výše uvedených položek

\begin{tabular}{|c|c|c|c|c|c|c|c|c|c|c|}
\hline & \multicolumn{2}{|c|}{$\begin{array}{l}\text { práce rozvijí } \\
\text { vlohy }\end{array}$} & \multicolumn{2}{|c|}{$\begin{array}{c}\text { peníze bez } \\
\text { práce ponižují }\end{array}$} & \multicolumn{2}{|c|}{$\begin{array}{c}\text { kdo nepracuje, } \\
\text { zleniví }\end{array}$} & \multicolumn{2}{|c|}{$\begin{array}{c}\text { práce je } \\
\text { povinnost vưči } \\
\text { společnosti }\end{array}$} & \multicolumn{2}{|c|}{$\begin{array}{l}\text { přednost práce } \\
\text { před volným } \\
\text { časem }\end{array}$} \\
\hline & ne & ano & ne & ano & ne & ano & ne & ano & ne & ano \\
\hline \multirow{2}{*}{ ČR 1999} & 16 & 1505 & 561 & 8 & 211 & 1498 & 333 & 1189 & 412 & 1043 \\
\hline & $8,5 \%$ & $79,5 \%$ & $29,8 \%$ & $46,8 \%$ & $11,1 \%$ & $79,1 \%$ & $17,6 \%$ & $62,9 \%$ & $22,0 \%$ & $55,7 \%$ \\
\hline \multirow{2}{*}{ ČR 2008} & 212 & 1309 & 451 & 837 & 292 & 1201 & 332 & 919 & 431 & 872 \\
\hline & $11,8 \%$ & $72,9 \%$ & $25,1 \%$ & $46,6 \%$ & $16,3 \%$ & $67,2 \%$ & $18,7 \%$ & $51,7 \%$ & $23.9 \%$ & $48,4 \%$ \\
\hline \multirow{2}{*}{ Slovensko 2008} & 89 & 1250 & 337 & 705 & 160 & 1041 & 209 & 893 & 240 & 873 \\
\hline & $5,5 \%$ & $84,6 \%$ & $23,1 \%$ & $48,2 \%$ & $10,8 \%$ & $70,3 \%$ & $14,3 \%$ & $61,0 \%$ & $16,3 \%$ & $59,4 \%$ \\
\hline \multirow{2}{*}{$\begin{array}{l}\text { Evropa } 2008 \\
\text { sever a západ }\end{array}$} & 4103 & 10448 & 7907 & 6524 & 6029 & 8450 & 4076 & 10434 & 8129 & 6425 \\
\hline & $28,2 \%$ & $71,8 \%$ & $54,8 \%$ & $45,2 \%$ & $41,6 \%$ & $58,4 \%$ & $28,1 \%$ & $71,9 \%$ & $55,9 \%$ & $44,1 \%$ \\
\hline \multirow{2}{*}{$\begin{array}{l}\text { Postkomunistické } \\
\text { zemé - Visegrád } \\
2008\end{array}$} & 1608 & 6024 & 3734 & 3734 & 2061 & 5568 & 2978 & 4617 & 3733 & 3881 \\
\hline & $21,1 \%$ & $78,9 \%$ & $49,2 \%$ & $49,2 \%$ & $27,0 \%$ & $73,0 \%$ & $39,2 \%$ & $60,8 \%$ & $49,0 \%$ & $51,0 \%$ \\
\hline
\end{tabular}

Poznámka: Ano = součet voleb „,rozhodně souhlasím“ a „,souhlasím“; ne = součet voleb „,rozhodně nesouhlasím“ a „,nesouhlasím“, v tabulce nejsou obsaženy podíly těch, kdo nevyjádřili ani souhlas, ani nesouhlas.

V roce 2008 dochází oproti roku 1999 v České republice k poklesu souhlasu se všemi výroky indikujícími pracovní étos, s výjimkou položky „je ponižující dostávat penize, aniž by si je člověk musel vydělat " (s tímto výrokem souhlasí stále asi polovina dotázaných). Míra souhlasu respondentů $\mathrm{v}$ České republice $\mathrm{s}$ tímto výrokem je obdobná míře zaznamenané v zemích západní Evropy. Podíl osob souhlasících s výrokem, že pracovat je povinností vůči společnosti, je v České republice (52\%) výrazně nižší než v zemích západní Evropy (72\%) a nachází se i pod průměrem zemí Visegrádu (61 \%). Podíl souhlasu s výrokem, že práce by měla mít vždy přednost, $i$ když to znamená mít méně volného času, mezi respondenty v České republice (48\%) se př́liš neliší od podílu souhlasu v zemích západní Evropy (44 \%), je však nižší ve srovnání se zeměmi Visegrádu, zejména pak ve srovnání se Slovenskem.

Pokud se zaměříme na diferenciační vliv vzdělání na míru souhlasu respondentů v České republice s položkami indikujícími étos práce, nacházíme rozdíl mezi osobami s nejvýše základním vzděláním a osobami s vyšším než základním vzděláním (jednotlivé stupně vzdělání uvnitř této skupiny dále míru souhlasu nediferencují). Rozdíly jsou ovšem velmi malé, i když jsou statisticky významné. Týkají se zejména výroku lidé, kteři nepracují, zleniví, se kterým souhlasí 53 \% osob, které dosáhly jen základního vzdělání, a 70 \% osob s vyšším dosaženým vzděláním, ale také výroku člověk musí mít práci, aby mohl plně rozvinout své vlohy. S tímto výrokem souhlasí $64 \%$ z těch, kdo dosáhli jen základního vzdělání, ale 74 \% z osob s vyšším dosaženým vzděláním. Zajímavá je shoda všech vzdělanostních stupňů $\mathrm{v}$ př́padě položky je ponižující dostávat penize, aniž by si je člověk musel vydělat; zde tedy není míra souhlasu dosaženým vzděláním nijak ovlivněna.

Rozdíly v míře souhlasu s těmito výroky nacházíme i mezi kohortami podle roku narození. Pro někoho možná překvapivě je tento souhlas vyšší u příslušníků kohort narozených po roce 1971 než v kohortách osob dříve narozených. Poměr souhlasu s výrokem člověk 
musí mit práci, aby mohl plně rozvinout své vlohy v nejstarších (narození před rokem 1960) a nejmladších kohortách (narození po roce 1971) je 75\%:85\%. V př́ípadě výroku lidé, kteři nepracují, zleniví je tento poměr $70 \%: 80 \%$, v př́padě výroku pracovat je povinností vioči společnosti $55 \%: 70 \%$ a v př́padě výroku práce by měla mít vždy přednost, $i$ když to znamená mít méně volného času $47 \%$ : 67\%. Ani zde však nenacházíme rozdíl v míre souhlasu $\mathrm{s}$ výrokem je ponižujicí dostávat penize, aniž by si je člověk musel vydělat. Pohlaví míru souhlasu s těmito výroky nijak nediferencuje.

\section{Práce jako relativní hodnota}

Porovnání důležitosti, kterou jedinci přisuzují práci, s důležitostí, již přisuzují dalším sférám svého života, konkrétně rodině a volnému času, ${ }^{12}$ nabízí tabulka 2.

Tabulka 2: Relativní hodnota práce: Důležitost práce, rodiny a volného času pro živoł

\begin{tabular}{|c|c|c|c|c|c|c|}
\hline & \multicolumn{2}{|c|}{ práce } & \multicolumn{2}{|c|}{ rodina } & \multicolumn{2}{|c|}{ volný čas } \\
\hline & ne & ano & ne & ano & ne & ano \\
\hline \multirow{2}{*}{ ČR 1991} & 74 & 2031 & 41 & 2062 & 519 & 1551 \\
\hline & $3,5 \%$ & $96,5 \%$ & $1,9 \%$ & $98,1 \%$ & $25,1 \%$ & $74,9 \%$ \\
\hline \multirow{2}{*}{ ČR 1999} & 121 & 1778 & 31 & 1870 & 397 & 1497 \\
\hline & $6,4 \%$ & $93,6 \%$ & $1,6 \%$ & $98,4 \%$ & $21,0 \%$ & $79,0 \%$ \\
\hline \multirow{2}{*}{ ČR 2008} & 311 & 1482 & 49 & 1758 & 249 & 1555 \\
\hline & $17,3 \%$ & $82,7 \%$ & $2,7 \%$ & $97,3 \%$ & $13,8 \%$ & $86,2 \%$ \\
\hline \multirow{2}{*}{ Slovensko 2008} & 101 & 1359 & 13 & 1489 & 197 & 1267 \\
\hline & $6,9 \%$ & $93,1 \%$ & $0,9 \%$ & $99,1 \%$ & $13,5 \%$ & $86,5 \%$ \\
\hline \multirow{2}{*}{$\begin{array}{l}\text { Evropa } 2008 \\
\text { sever a západ }\end{array}$} & 948 & 12902 & 320 & 14224 & 1357 & 13161 \\
\hline & $6,8 \%$ & $93,2 \%$ & $2,2 \%$ & $97,8 \%$ & $9,3 \%$ & $90,7 \%$ \\
\hline \multirow{3}{*}{$\begin{array}{l}\text { Postkomunistické } \\
\text { země - Visegrád } 2008\end{array}$} & 544 & 6875 & 112 & 7541 & 926 & 6598 \\
\hline & $7,3 \%$ & $92,7 \%$ & $1,5 \%$ & $98,5 \%$ & $12,3 \%$ & $87,7 \%$ \\
\hline & $8,6 \%$ & $91,4 \%$ & $1,6 \%$ & $98,4 \%$ & 19,3 & $80,7 \%$ \\
\hline
\end{tabular}

Zdroj: EVS, Česká republika 1991, 1999 a 2008.

V roce 1991 byli prakticky všichni respondenti přesvědčeni o tom, že práce hraje v jejich životě důležitou roli ( $97 \%$ ), stejně tak na tom ale bylo i posouzení důležitosti rodiny (98 \%), zatímco volný čas tehdy považoval za důležitý menší podíl respondentů (75\%). Mezi lety 1991 až 2008 se tyto distribuce proměňují. Konstantní hodnotou zůstává i v roce 2008 důležitost rodiny (97 \%). Zvyšuje se ale podíl těch, v jejichž životě hraje důležitou roli

12 Otázka v dotazníku ve všech letech zněla: „Prosím řekněte, pro každou z následujících skutečností (práce, rodina, přátelé a známí, volný čas, politika, náboženství), jak jsou ve Vašem životě důležité " a nabízela varianty velmi důležitá, dosti důležitá, ne príliš důležitá a vůbec nedưležitá. Tabulka 2 obsahuje tuto škálu dichotomizovanou. 
volný čas (86 \%), a podíl těch, kdo považují za důležitou ve svém životě práci, ve sledovaných letech klesá (i když stále zůstává značný - v roce 2008 to bylo 83 \%). Tento pokles je poněkud překvapivý ve srovnání se zeměmi západní Evropy, ale i zeměmi Visegrádu, a zde i ve vztahu ke Slovensku (ve všech třech případech cca $93 \%$ ). V míře významu přisuzované volnému času se tedy Evropě přibližujeme, v míře významu připisované práci naopak vzdalujeme. ${ }^{13}$

Podíl těch, kdo považují práci za důležitou ve svém životě, je v České republice vysoký v kohortách osob narozených do roku 1960 (přes $90 \%$ ), v kohortách narozených po roce 1960 tento podíl klesá (na cca 70 \%), což je možná poněkud překvapující ve vztahu ke zjištění o jejich podílu souhlasu s výroky indikujícími pracovní étos. Mezi osobami s pouhým základním vzděláním je podíl těch, kdo práci považují za důležitou, v roce 2008 menší (68\%, přičemž tato hodnota představuje také výrazný pokles ve srovnání s $93 \% \mathrm{v}$ roce 1991) než mezi osobami s vyšším než základním vzděláním (mezi osobami se středním vzděláním nebo vyučenými dosahuje podíl těch, kdo označují práci za důležitou, $85 \%$, mezi osobami s vysokoškolským vzděláním $94 \%$ ). Trend změn podílu těch, kdo akcentují ve svém životě důležitost volného času, je opačný. Ve sledovaných letech rostl ve všech vzdělanostních kategoriích, největší rozdíl mezi lety 1991 a 2008 je u skupiny osob dosahujících jen základního vzdělání. Je to dáno také nižší výchozí úrovní roku 1991 v této skupině - jen $67 \%$ oproti $76 \%$ mezi osobami vyučenými a osobami se středním vzděláním a $80 \%$ mezi osobami s vysokoškolským vzděláním.

$\mathrm{Na}$ datech, která máme $\mathrm{k}$ dispozici, lze vztah práce/zaměstnání a rodiny sledovat i nepř́mo, prostřednictvím postojů zaujímaných $\mathrm{k}$ zaměstnanosti žen. Podíl osob souhlasících s tím, že být ženou v domácnosti ji naplňuje stejně, jako práce za mzdu, klesl z $84 \%$ v roce 1991 na $77 \%$ v roce 1999 a dále na $53 \%$ v roce 2008 , a to na $49 \%$ mezi ženami a na $58 \%$ mezi muži. Tento pokles se zvýrazňoval také s růstem vzdělání dotazovaných osob, v roce 2008 poklesl na $61 \%$ u osob se základním vzděláním, na $55 \%$ u osob vyučených, na $48 \%$ u osob se středoškolským a na $40 \%$ u osob s vysokoškolským vzděláním. Nenašli jsme ale $\mathrm{v}$ tomto ohledu rozdíly $\mathrm{v}$ postojích jednotlivých kohort vymezených rokem narození. Klesá také podíl respondentů, kteří souhlasí s tím, že předškolní děti asi trpí, jestliže je jejich matka zamèstnaná. A to ze $70 \% \mathrm{v}$ roce 1991 na $48 \%$ v roce 1999 a na $43 \%$ v roce 2008 . Podíl těch, kdo si myslí, že při nedostatku pracovních př́ležitostí by zaměstnavatelé měli dát přednost mužům před ženami, se snížil z $51 \%$ v roce 1991 na $28 \%$ v roce 2008 , a to ve všech věkových skupinách. Nejvíce pak, také vzhledem k vysoké výchozí hodnotě v roce 1991 (68 \%), mezi osobami narozenými před rokem 1949. Více se snížil mezi ženami (z 52\% v roce 1991 na $22 \%$ v roce 2008 ), méně mezi muži (ze $49 \%$ v roce 1991 na $34 \%$ v roce 2008$)$.

13 Teprve výsledky další vlny ovšem mohou naznačit, zda jde skutečně o trend, jak tomu stálý pokles podílu těch, kdo práci ve svém životě považují za důležitou, nasvědčuje. Nebo zda jde jen o roční výkyv či dokonce jen o statistický artefakt. 


\section{Hodnota jednotlivých charakteristik práce}

Respondenti se $\mathrm{v}$ jednotlivých vlnách EVS vyjadřovali také $\mathrm{k}$ tomu, jak důležité jsou pro ně jednotlivé charakteristiky práce. Použitá hierarchická shluková analýza proměnných pak tyto charakteristiky v datovém souboru ČR z roku 2008 seskupila do čtyř základních shluků..$^{14}$ První z nich bychom mohli nazvat materiální/instrumentální aspekty práce a tvoří ho položky „dobrý plat“ (podíl těch, kdo přisuzovali hodnotu dobrému platu, v čase rostl a v roce 2008 dosáhl $87 \%$, podobně tomu bylo v zemích Visegrádu, zatímco v zemích severozápadní Evropy ho zmínilo $68 \%$ dotázaných) ${ }_{15}^{15}$,jistota, že nepřijdete o místo“ (zmínilo ji v ČR $61 \%$, v zemích Visegrádu dokonce $72 \%$, zatímco v zemích severozápadní Evropy $57 \%$ dotázaných) a s nimi volněji spojené položky „zajímavá práce“ (67 \%), „práce, kde se s lidmi zachází spravedlivě“ (66\%) a „př́jemní spolupracovníci“ (72\%). V druhém shluku se seskupily položky „výhodná pracovní doba“ (48\%), „dlouhá dovolená“ (37\%) a „,nepracovat pod př́lišným tlakem“ (48\%) a mohli bychom ho nazvat aspekty práce, týkajici se komfortu jejího výkonu. Třetí shluk bychom mohli nazvat seberealizačni aspekty práce a vytvářejí ho položky „práce, ve které můžete něčeho dosáhnout“ (50 \%), „práce, ve které člověk využije svých schopností“ (57\%) a „možnost naučit se novým dovednostem“ (46 \%). Mezi léty 1991-2008 nepozorujeme jednoznačný trend $\mathrm{k}$ růstu nebo poklesu podílu osob, považujících tyto položky za důležité. Za zmínku stojí jen to, že podíl těch, pro něž je důležitá práce, v níž využijí vlastních schopností, klesl z vysoké hodnoty v roce 1991 (70 \%) již v roce 1999 na nižší hodnotu (57\%) a udržel se na ní i v roce 2008. Čtvrtý shluk je pak složen z položek „př́ležitost uplatnit iniciativu“ (39 \%), ,společensky užitečná práce“ (v ČR ji zmínilo 41\%, v zemích Visegrádu 39\% a v zemích severozápadní Evropy 36\% dotázaných), „možnost setkávat se s lidmi“ (43\%), ,zodpovědná práce“ (39\%) a „možnost účastnit se na důležitých rozhodnutích“ (31\%) a mohli bychom ho nazvat společenské aspekty práce. Ani zde nepozorujeme mezi lety 1991-2008 jednoznačný trend k růstu nebo poklesu podílu osob, považujících tyto položky za důležité (i když v roce 2008 oproti výchozímu roku 1991 mírně klesl podíl těch, kdo akcentují společenskou užitečnost své práce). K třetímu a čtvrtému shluku se ještě volně pojí důraz na „vstřícnost práce k rodinnému životu“ (45\%). Nejde samozřejmě o výsledek neočekávaný a koresponduje s výše uvedenými dřivějšími pokusy charakteristiky práce klasifikovat.

14 Otázka v dotazníku zněla: „Zde je výčet toho, co lidé považuji za důležité ve své práci. Prosím, prohlédněte si seznam a řekněte mi, co z něj Vy osobně považujete za důležité?" a nabízela tyto charakteristiky práce: dobrý plat; prríjemni spolupracovnici; nepracovat pod přilišným tlakem; jistota, že nepřijdete o místo; výhodná pracovní doba; př́ležitost uplatnit iniciativu; společensky užitečná práce; dlouhá dovolená; možnost setkávat se s lidmi; práce, ve které můžete něčeho dosáhnout; zodpovědná práce; zajímavá práce; práce, v niž člověk využije své schopnosti; naučit se novým dovednostem; vstřicná vi̊či rodinnému životu; práce, v niž se člověk může účastnit na důležitých rozhodnutich; práce, kde se s lidmi zacházi spravedlivě. Protože jde o dichotomické proměnné, dali přednost shlukové analýze před analýzou faktorovou (i když se lze v literatuře i v těchto př́padech s použitím faktorové analýzy setkat).

15 V hierarchické shlukové analýze byla použita metoda between-groups linkage a squared Euclidean distance. V závorce za každou jednotlivou charakteristikou práce uvádíme podíl osob, které ji považovaly v roce 2008 za důležitou. 
Důležitost materiálních/instrumentálních charakteristik práce tedy akcentuje vyšší podíl osob než důležitost jejích seberealizačnich či společenských charakteristik. Co se týče seberealizačnich aspektů práce, neliší se situace v České republice př́liš od situace většiny evropských zemí. Důležitost něčeho v práci dosáhnout zde zmínilo $50 \%$, v zemích Visegrádu $58 \%$ a v zemích severozápadní Evropy $56 \%$ dotázaných. Důležitost využití svých schopností pak zmínilo v České republice i v zemích Visegrádu 57\% a v zemích severozápadní Evropy 56\% dotázaných.

Důležitost přikládaná v ČR jednotlivým charakteristikám práce je ovlivňována zejména vzděláním a věkem. V př́ípadě materiálních/instrumentálních aspektů práce není frekvence podílu osob akcentujících důležitost ,dobrého platu“ vzděláním ovlivněna, v případě ,jistoty, že nepřijdete o místo" to ovšem tak zcela neplatí, nebot's růstem vzdělání podíl těch, kdo tuto charakteristiku práce považují za důležitou, klesá. „Dobrý plat“ je zmiňován s největší frekvencí ve všech věkových skupinách, jen v nejmladších je tato frekvence o něco málo nižší (od roku narození 1971), v př́padě ,jistoty, že nepřijdete o místo “ je tato frekvence o něco nižší, ale stále patř́i k nejčetnějším, a to opět ve všech kohortách. Jen s tou výjimkou, že nejmladší kohorta ji (na rozdíl od položky „dobrý plat") zmiňuje častěji než ostatní kohorty. Akcent na sociální aspekty práce je jak v případě „zodpovědné práce“, tak i v př́ípadě „,společensky užitečné práce“ větší u vzdělanějších osob (roste se vzděláním). „Zodpovědná práce“ je zmiňována všemi, nezávisle na jejich věku, přibližně se stejnou frekvencí, „společensky užitečná práce“ je zmiňována méně častěji mladšími kohortami (narození od roku 1961). Také akcent na seberealizačni aspekty práce je, stejně jako tomu bylo u společenských aspektů práce, doménou vzdělanějších osob. Podíl těch, kdo přisuzují důležitost ,práci, v níž lze něčeho dosáhnout“, i těch, kdo přisuzují důležitost „práci, v níž se využije schopností", roste s vyšším vzděláním respondentů. Seberealizační aspekt práce je důležitý stejnou měrou pro všechny věkové skupiny v př́padě charakteristiky „práce, ve které můžete něčeho dosáhnout“. Ne však tak docela $v$ prípadě „práce, v níž člověk využije své schopnosti““ (kohorta narozených po roce 1971 a socializovaná tedy v období normalizace zmiňuje důležitost této charakteristiky o něco méně často než ostatní kohorty).

\section{Spokojenost s prací}

V roce 2008 vyjádřilo v České republice $56 \%$ respondentů spokojenost se svojí prací. Byl to stejný podíl jako v zemích Visegrádu a více než v zemích bývalého Sovětského svazu (46\% dotázaných v Rusku a na Ukrajině a $36 \%$ v ostatních sledovaných následnických státech SSSR - Arménii, Azerbajdžánu a Gruzii), ale méně než v zemích západní Evropy (65 \%). ${ }^{16}$ Tento podíl osob spokojených s prací se udržoval v České republice ve zhruba všech sledovaných letech (v roce 1991 to bylo $51 \%$, v roce 1999 to bylo $55 \%$ a v roce 2008 dosáhl podíl spokojených s prací $56 \%$ ). Ukazuje se přitom středně silná asociace mezi spokojeností s prací a spokojeností v životě (Spearmanův koeficient v souboru České republiky 0,365; v souboru zemí severozápadní Evropy 0,403; v obou př́padech HV=0,01).

16 Původní jedenáctistupňová škála modifikována sloučením hodnot 1-4 jako „,nespokojen/a“, 5-6 jako střed a 7-11 jako,,spokojen/a“. 
Spokojenost s prací není ovlivněna pohlavím (mezi muži stejně jako mezi ženami nacházíme $56 \%$ spokojených s prací), co se týče vlivu věku, je největší podíl spokojených mezi osobami čtyřiceti- až padesátiletými. Proměnnou, která výrazně ovlivňuje spokojenost s prací, je pak vzdělání. Všechny vzdělanostní skupiny začínaly v roce 1991 na stejné pomyslné startovací čáre cca $50 \%$ osob spokojených s prací, ale další vývoj vedl k diferenciaci této spokojenosti v závislosti na vzdělání. Zatímco ve skupině osob, které dosáhly pouze základního vzdělání, je v roce 2008 jen 40 \% spokojených (jejich podíl je v letech 1991-2008 celkem konstantní), mezi vyučenými je to 52\% (trend v letech 1991-2008 je stejný jako u předchozí vzdělanostní skupiny), mezi osobami se středním vzděláním je to $63 \%$ (znamená to mírný růst z 52\% v roce 1991) a mezi osobami, které dosáhly vysokoškolského vzdělání, to je $70 \%$ (což je výrazný růst z $50 \%$ v roce 1991 ).

\section{Identifikace typů - aplikace latentní shlukové analýzy}

K identifikaci proměny hodnoty práce a hodnoty jednotlivých charakteristik práce v české společnosti mezi roky 1991, 1999 a 2008 použijeme též latentní shlukovou analýzu. Oproti výsledkům klasické shlukové analýzy mají výsledky této analýzy kategoriální povahu a pro naše indikátory, jejichž povaha je právě kategoriální, je tato metoda numericky vhodnější, protože vzdálenosti mezi variantami indikátorů neznáme. ${ }^{17}$ Naše analýza má dvě části.

Nejprve se budeme zabývat praci jako relativni životni hodnotou a budeme zjišt'ovat, jaké typy mužů a žen se v české společnosti vymezují na základě důležitosti, kterou jedinci přisuzují ve svém životě práci, práteliom a známým, volnému času, politice a náboženství (jde o dichotomické proměnné, na dotaz po jejich důležitosti respondenti odpovídali bud'ano, nebo ne), vezmeme-li současně do úvahy další proměnné (věk, nejvyšší dosažené vzdělání a rok sběru dat).

V druhé části se budeme analogickým způsobem zabývat hodnotou jednotlivých charakteristik práce tak, jak je výběrové šetření European Values Study sledovalo. Analyzovat ovšem budeme pouze pět charakteristik práce: plat, jistotu, zodpovědnost, užitečnost a schopnosti. Analytické použití indikátoru ,práce, v níž lze něčeho dosáhnout“ se ukázalo jako

17 Latentní shluková analýza je součástí analýzy latentních tříd, kterou do sociálních věd v padesátých letech minulého století uvedl Lazarsfeld (srovnej Lazarsfeld a Henry 1968). Během sedmdesátých a osmdesátých let byla tato analýza formalizována a zobecněna především díky pracím Goodmana (1974) a Clogga (1981). V devadesátých letech se postupně stává běžnou součástí sociologických analýz (srovnej např́klad Hagenaars 1993, Clogg 1995, Vermunt 1997, Hagenaars a McCutcheon 2002, Magidson a Vermunt 2004). Cílem latentní shlukové analýzy je identifikovat $K$-kategorií latentní (nominální) proměnné, přičemž každá její kategorie reprezentuje shluk ve zkoumané populaci. Takové kategorie nejsou př́mo pozorovatelné - s ohledem na indikátory (kritéria použitá v dotazování) se ovšem jedná o homogenní skupiny (konstruované na základě pravděpodobnosti), jež jsou reprezentovány lidmi, kteří sdílejí názory, hodnoty a postoje, tedy společný model parametrů, konstatují Vermunt a Magidson (2005). Na rozdíl od „tradičního“ př́stupu identifikace latentních proměnných, jako je faktorová analýza, analýza latentních shluků předpokládá, že povaha znaků v sociální realitě není spojitá, ale diskrétní (k diskusi o spojité versus kategorizované/diskrétní povaze zkoumané reality více srov. Powers, Xie, 2000). 
redundantní, z analytického hlediska ho vyčerpávají zbylé indikátory (především „společensky užitečná práce“ a ,práce, $v$ níž využiji vlastních schopnosti'“). V tomto př́ípadě nás zajímá, jak těchto pět indikátorů jednotlivých charakteristik práce diferencuje českou společnost; jaké sociální skupiny z hlediska př́istupu k práci v české společnosti tedy existují, jak se tyto skupiny proměňují v analyzovaných letech a jak je podmiňují zvolené sociální charakteristiky (věk a vzdělání).

\section{Česká společnost v letech 1991-2008 z hlediska hodnoty práce}

Tabulka 3 ukazuje statistická kritéria odhadnutých modelů latentní shlukové analýzy pro souhlas či nesouhlas s vybranými životními hodnotami (práce, přátelé, volný čas, politika a náboženství). Model 1 přepokládá existenci jednoho shluku, Model 2 dvou shluků a každý další model (model 3 až 5) přidává $\mathrm{k}$ modelu 2 o jeden shluk v české populaci víc. Přidáváním shluků do modelů zvyšujeme jejich přesnost. Poměr maximální věrohodnosti $\left(L^{2}\right)$ se přibližuje 0 (modelu $\mathrm{s}$ nejvyšší přesností), zároveň ovšem také roste klasifikační chyba (podíl prípadů, které jsou neadekvátně zařazeny). Rovnováhu mezi poměrem maximální věrohodnosti a klasifikační chybou indikuje statistika $B I C$, která zohledňuje velikost maximálně věrohodnostní funkce a počet parametrů $\mathrm{s}$ ohledem na počet případů $\mathrm{v}$ modelu..$^{18}$ Na základě této statistiky lze naše data interpretovat s pomocí modelu M3, který předpokládá existenci tř́ shluků v české společnosti. Z hlediska životních hodnot nemůžeme tedy považovat českou populaci za homogenní a je nezbytné v jejím rámci rozlišit sociální skupiny. Abychom tyto skupiny (shluky) interpretačně lépe identifikovali, odhadli jsme k modelu 3 model 6, který obsahuje vysvětlující proměnné rok (1991, 1998, 2009), vzdělání (bez maturity/maturita) ${ }^{19}$ a věk (18-30 let, 31-45 let, 46-60 let). Podle BIC statistiky model 6 poskytuje více informací o zkoumané realitě než model 3. Identifikace shluků na základě tohoto modelu je rovněž snazší (model charakterizuje shluky více informacemi). Naše data budeme proto interpretovat na základě tohoto modelu.

Tabulka 4 ukazuje podíly české společnosti připadající na jednotlivé shluky na základě modelu 6. Velmi zhruba můžeme konstatovat, že česká společnost se z hlediska analyzovaných hodnot dělí na třetiny. Do prvního shluku přináleží $35 \%$ populace. Druhý shluk je velikostně stejný jako první; třetí shluk tvoří $30 \%$ populace.

18 BIC je zkratkou pro Bayesovské informační kritérium, které je konstruováno tak, aby indikovalo model, jehož informační hodnota o zkoumané realitě je nejvyšší. Obecně platí, že čím nižší číslo statistika $B I C$ indikuje, tím adekvátnější informaci o realitě nám model poskytuje: $B I C(L L)=-2$ $\log L+(\log N) x$ (počet parametrů).

19 Vzdělání je v tomto př́padě (z důvodů interpretačních) dichotomizováno na dvě kategorie: bez maturity a maturita. Tyto varianty jsme vytvořili z původních čtyř variant proměnné vzdělání základní, vyučen/a, středoškolské a vysokoškolské - sloučením prvních dvou a zbylých dvou variant. 
Tabulka 3: Odhadnuté parametry latentní shlukové analýzy pro vybrané životní hodnoty v české společnosti

\begin{tabular}{ccccccc}
\hline \multicolumn{9}{c}{$\begin{array}{c}\text { Vrchol } \\
\text { věrohod. } \\
\text { funkce } \\
\text { Model }\end{array}$} & $\begin{array}{c}\text { Popis } \\
\text { modelu }\end{array}$ & (LL) & BIC & df & p-value & $\begin{array}{c}\text { Klasifikační } \\
\text { chyba }\end{array}$ \\
\hline M1 & 1-Cluster & -9000.99 & 58 & 26 & 0.000 & 0.00 \\
M2 & 2-Cluster & -8930.20 & -34 & 20 & 0.000 & 0.21 \\
M3 & 3-Cluster & -8875.57 & -93 & 14 & 0.049 & 0.31 \\
M4 & 4-Cluster & -8869.80 & -54 & 8 & 0.140 & 0.32 \\
M5 & 5-Cluster & -8866.60 & -11 & 2 & 0.055 & 0.36 \\
& 3-Cluster & & & & & \\
M6 & + covariáty & -8668.22 & -3760 & 531 & 0.000 & 0.29 \\
\hline
\end{tabular}

Tabulka 4: Velikost shluků pro vybrané životní hodnoty v české společnosti (Model 6)

\begin{tabular}{lccc}
\hline & Cluster1 & Cluster2 & Cluster3 \\
\cline { 2 - 4 } Velikost clusteru & $35.16 \%$ & $34.78 \%$ & $30.07 \%$ \\
\hline
\end{tabular}

V latentní shlukové analýze lze na základě podmíněné pravděpodobnosti souhlasu či nesouhlasu s daným indikátorem jednotlivé shluky od sebe interpretačně odlišit. Obrázek 1 ukazuje jednak pravděpodobnost souhlasu s danou životní hodnotou, jednak pravděpodobnost pro každý shluk z hlediska vysvětlujících proměnných. To znamená, že vidíme pravděpodobnost výskytu v jednotlivých letech sběru dat (1991, 1999 a 2008), pravděpodobnost, že budou mít v daném shluku lidé maturitu (zbylá pravděpodobnost připadá na vzdělání bez maturity), a pravděpodobnost pro jednotlivé věkové skupiny být součástí každého ze shluků. Jedná se o diference ve vzorcích odpovědí podle identifikovaných tří shluků.

První shluk tvoří respondenti považující práci a prrátele za důležitější než volný čas. Oproti respondentům ve zbylých dvou shlucích zdůrazňují význam politiky a šance, že budou religiózně orientovaní, je u nich rovněž vyšší, než u respondentů ve druhém a třetím shluku. Od roku 1991 do roku 2008 se pravděpodobnost výskytu tohoto shluku v populaci zmenšuje. Jedná se především o lidi vzdělané (s maturitou nebo vysokoškolským vzděláním) a starší (především ve věku 46 až 60 let). Respondenti ve druhém shluku považují přátele a volný čas ve svém životě za důležitější než práci. Politika a náboženství v tomto shluku nehrají prakticky žádnou roli. V čase (mezi roky 1991 až 2008) tento shluk roste. Úroveň vzdělání je v tomto shluku nižší než v shluku prvním a z hlediska věku se jedná především o respondenty mladé (ve věku 18 až 30 let). Třetí shluk je velikostně o něco menší než předchozí dva. Respondenti tohoto shluku zdůrazňují význam práce prakticky ve stejné míře jako respondenti prvního shluku, na přátele a volný čas se však orientují výrazně méně než je tomu u předchozích dvou shluků. Pravděpodobnost, že se budou zajímat o politiku a náboženství, je u nich o něco vyšší než u druhého shluku, přitom ale výrazně nižší než u shluku prvního. Podobně jako u prvního i u tohoto shluku se pravděpodobnost jeho výskytu v čase zmenšuje. Z hlediska vzdělání tvoří tento shluk především respondenti bez maturity (s výučním listem), kteří jsou nejčastěji ve věku 31 až 45 let. 
Obrázek 1: Pravděpodobnost souhlasu s jednotlivými životními hodnotami (Model 6)

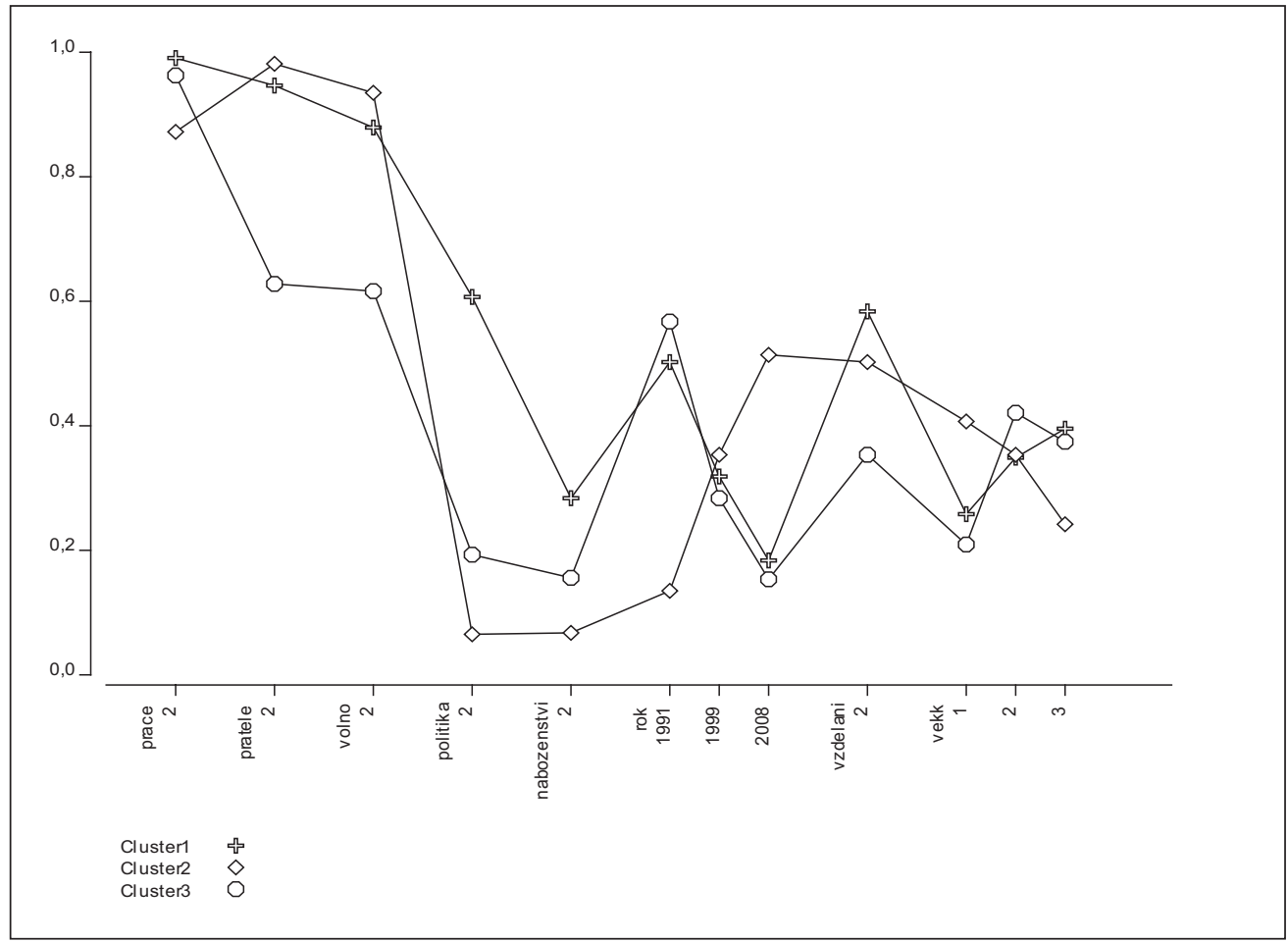

\section{Česká společnost v letech 1991-2008 z hlediska hodnoty jednotlivých charakteristik práce}

Pět charakteristik (indikátorů) konceptu práce (plat, jistotu, zodpovědnost, užitečnost a schopnosti) jsme analyzovali podobným způsobem jako hodnotu práce. Nejprve jsme odhadli pět modelů latentní shlukové analýzy: model 1 předpokládal existenci jednoho shluku, Model 2 existenci dvou shluků a každý další model existenci jednoho shluku navíc oproti Modelu 2. Tabulka 5 ukazuje, že BIC statistika je pro model 3 nejnižší ve srovnání s ostatními modely. Českou společnost nemůžeme tedy ani z hlediska charakteristik práce považovat za homogenní. $\mathrm{V}$ jejím rámci je nezbytné rozlišit tři shluky. $\mathrm{K}$ modelu 3 jsme stejně jako v předchozí analýze odhadli model 6 , který obsahuje vysvětlující proměnné rok a vzdělání. ${ }^{20}$ BIC statistika ukazuje, že model 6 poskytuje více informací o zkoumané realitě než model M3. Naše identifikace a interpretace struktury české společnosti z hlediska jednotlivých charakteristik práce se proto bude zakládat na tomto modelu.

20 Kovariát věk v tomto př́ípadě neměl věcné opodstatnění, nebot' z hlediska identifikovaných shluků prakticky nevarioval. 
Tabulka 5: Odhadnuté parametry latentní shlukové analýzy z hlediska jednotlivých charakłeristik práce $v$ české společnosti

\begin{tabular}{|c|c|c|c|c|c|c|}
\hline Model & $\begin{array}{l}\text { Popis } \\
\text { modelu }\end{array}$ & $\begin{array}{l}\text { Vrchol } \\
\text { věrohod. } \\
\text { funkce } \\
\text { (LL) }\end{array}$ & $\mathrm{BIC}$ & df & $\mathrm{p}$-value & $\begin{array}{c}\text { Klasifikační } \\
\text { chyba }\end{array}$ \\
\hline M1 & 1-Cluster & -13699.39 & 1652 & 26 & 0.00 & 0.00 \\
\hline$M 2$ & 2-Cluster & -12880.16 & 64 & 20 & 0.00 & 0.09 \\
\hline M3 & 3-Cluster & -12783.99 & -78 & 14 & 0.00 & 0.18 \\
\hline M4 & 4-Cluster & -12772.45 & -51 & 8 & 0.05 & 0.28 \\
\hline M5 & $\begin{array}{l}\text { 5-Cluster } \\
\text { 3-Cluster }\end{array}$ & -12766.20 & -14 & 2 & 0.21 & 0.24 \\
\hline M6 & + covariáty & -12545.69 & -960 & 163 & 0.00 & 0.19 \\
\hline
\end{tabular}

Tabulka 6 ukazuje podíly české společnosti pro jednotlivé shluky charakteristik práce na základě modelu 6. Do prvního shluku přináleží více jak dvě pětiny české společnosti (43\%). Do druhého shluku spadá třetina české společnosti (29\%). Na zbylý, tř̌etí shluk připadá $27 \%$ české společnosti.

Tabulka 6: Velikost shluků pro jednotlivé charakteristiky práce v české společnosti (Model 6)

\begin{tabular}{lrrr}
\hline & Cluster1 & Cluster2 & Cluster3 \\
\cline { 2 - 4 } Velikost clusteru & $43.09 \%$ & $29.70 \%$ & $27.21 \%$ \\
\hline
\end{tabular}

Obrázek 2 ukazuje pravděpodobnost důležitosti daných charakteristik práce, pravděpodobnost výskytu identifikovaných shluků v analyzovaných letech a pravděpodobnost, že budou respondenti přináležet do jednotlivých shluků podle výše svého vzdělání (podle toho, zdali mají či nemají maturitu). Stejně jako v předchozí analýze i zde se jedná o rozdíly ve vzorcích odpovědí respondentů rozdělených do tří skupin (shluků).

V prvním shluku (největším) má všech pět indikátorů konceptu práce poměrně vysokou pravděpodobnost výskytu. Plat a schopnosti zde však dominují nad zodpovědností a užitečností. První shluk tedy tvoří především respondenti chápající práci z hlediska ekonomického př́ijmu a také jako prostředí, kde využijí své schopnosti. Jedná se o kombinaci materiálního/ instrumentálního a seberealizačního aspektu práce. Toto vnímání práce dominovalo v roce 1991, v roce 1999 pravděpodobnost tohoto shluku poklesla, v roce 2008 se však vrátila na úroveň roku 1991. Respondenti s takovým chápáním práce jsou především středoškolského vzdělání.

Oproti prvnímu shluku jsou zbylé dva shluky jednoznačněji identifikovatelné. Druhý shluk tvoří respondenti orientující se především na materiální/instrumentální aspekty práce (dobrý plat a jistotu, že neprrijdou o místo). Tento shluk prakticky vůbec neformuje zodpovědnost a společenská užitečnost práce. Jeho velikost v čase mírně roste a tvoří jej respondenti s nejnižším vzděláním (vyučení). Třetí shluk (nejmenší) tvoří respondenti orientující se na sociální a seberealizační aspekty práce (zodpovědná a užitečná práce, včetně využití 
individuálních schopností). Tento shluk prakticky neformuje jistota práce a seberealizační aspekt práce $\mathrm{v}$ něm dominuje. $\mathrm{V}$ čase tento shluk mizí. V roce 2008 už najdeme jen velmi malou pravděpodobnost jeho výskytu $\mathrm{v}$ české společnosti. Tvoří ho lidé $\mathrm{s}$ nejvyšším vzděláním. I u osob s nejvyšším vzděláním tak v čase klesá důležitost, kterou připisují práci jako prostoru k seberealizaci.

Obrázek 2: Pravděpodobnost souhlasu s jednotlivými charakteristikami práce (Model 6)

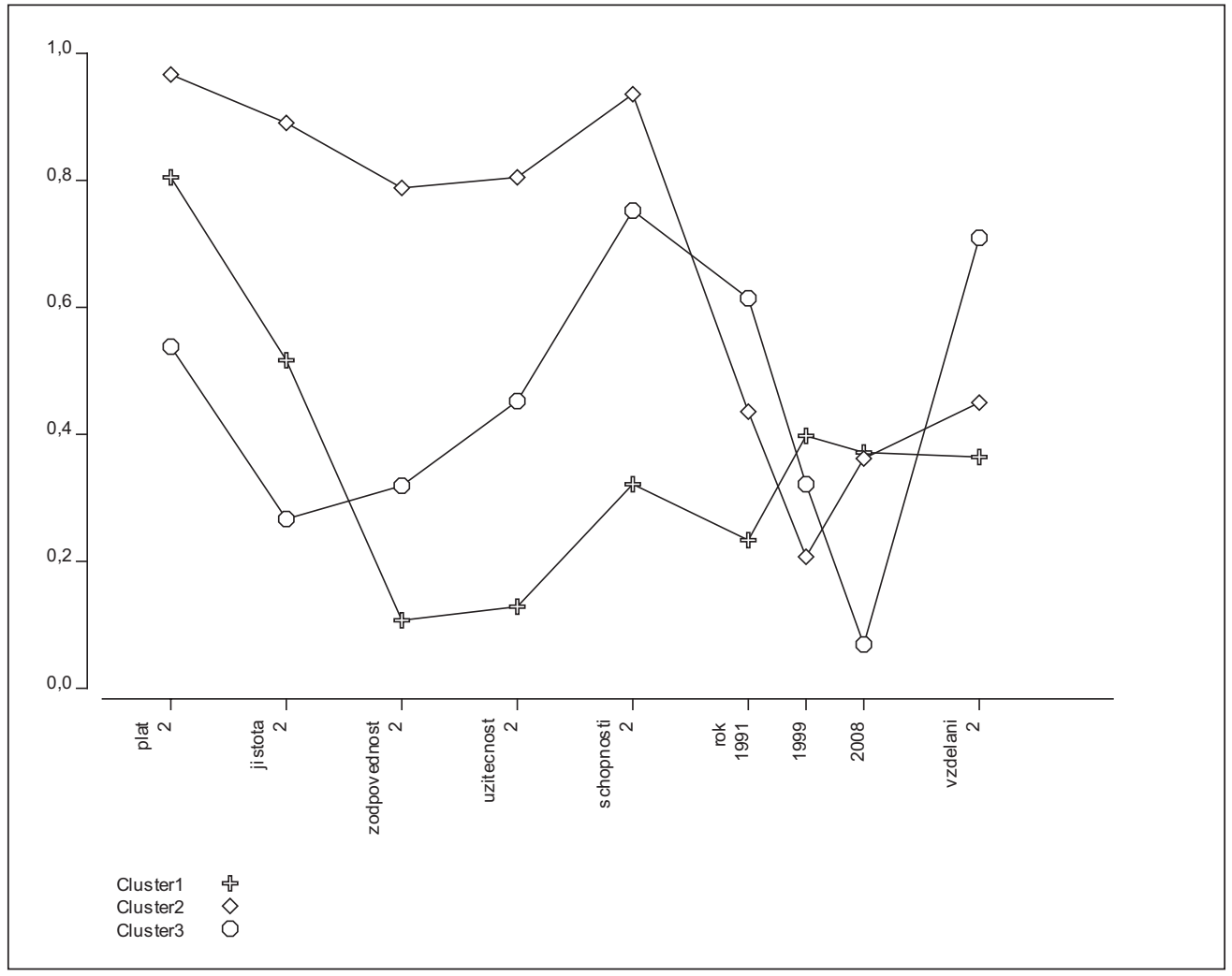

\section{Závěr}

V tomto textu jsme se zaměřili na to, jak se v datech EVS po roce 1991 v České republice měnila absolutní a relativní hodnota (placené) práce a jak se proměnilo vnímání jednotlivých charakteristik práce. Naše analýza ukázala, že hodnota práce (étos práce) je v České republice vysoká, ale ve sledovaném období došlo k poklesu u všech jejích indikátorů, pouŽivaných v EVS. V tomto ohledu se v roce 2008 populace České republiky přiblížila rozvinutým zemím severozápadní Evropy (a není v tomto ohledu diferencována, s výjimkou 
vyššího důrazu na pracovní étos u osob s vysokoškolským vzděláním a u mladší generace). Výjimkou je indikátor ,pracovat je povinností vůči společnosti“, míra souhlasu s tímto výrokem je v České republice oproti těmto zemím výrazně nižší (jako ostatně i v dalších zemích Visegrádu). Podíl těch, kdo považují práci ve svém životě za důležitou, klesá a v populaci České republiky je menší než v zemích severozápadní Evropy i než v zemích Visegrádu. Roste naopak podíl těch, kdo zdůrazňují důležitost volného času (v tomto př́ípadě se přibližujeme zemím severozápadní Evropy a vzdalujeme zemím Visegrádu). Výrazně od roku 1991 poklesl podíl osob považujících práci ve svém životě za důležitou, zejména mezi osobami jen se základním vzděláním, kde také výrazně rostl podíl těch, kdo zdůrazňují důležitost volného času.

Naše analýza rovněž ukázala, že se v populaci České republiky po roce 1991 měnily preference jednotlivých charakteristik práce. Rostla důležitost instrumentálních charakteristik ve srovnání s významem charakteristik sociálních (zde klesl zejména podíl těch, kdo zdůrazňují „společenskou užitečnost práce“) či seberealizačních (jejich význam byl v roce 1991, kdy byly nejvýše ceněny „dobrý plat“ a „práce, v níž člověk využije svých osobních schopnosti“", vyšší než v roce 2008, kdy je nejvíce ceněn především „dobrý plat“). Výrazným diferenciačním kritériem je zde dosažená úroveň vzdělání, zejména se od sebe vzdalují preference osob jen se základním vzděláním a osob s vysokoškolským vzděláním. Platí to zejména v př́ípadě sociálních a seberealizačních aspektů práce, jejichž důležitost pro vysokoškolsky vzdělané osoby roste, zatímco pro osoby se základním vzděláním klesá.

Spokojenost s prací (stejně jako spokojenost se životem - obě proměnné jsou středně silně asociovány) je v České republice (55\%) nižší než v původních zemích EU (před jejím rozširrením po roce 1990) se silnou ekonomikou (65\%, Nizozemí dokonce $75 \%$ a Dánsko $85 \%$ ), je však srovnatelná se zeměmi, jako jsou Portugalsko a vysoko nad nástupnickými státy Sovětského svazu ( $46 \%$ v jeho evropské a $35 \%$ v jeho asijské části).

Latentní shluková analýza ukázala, že českou společnost nelze považovat $\mathrm{z}$ hlediska hodnoty práce za homogenní. Identifikovali jsme tři skupiny lidí aktivních na trhu práce. První a největší skupina považuje práci a přátele za jednu z nejdůležitějších hodnot ve svém životě, pro druhou skupinu jsou přátelé a volný čas důležitější než práce a ve třetí, nejmenši skupině dominuje pouze práce nad ostatními životními hodnotami. Pravděpodobnost vyššího vzdělání a vyššího věku je u prvních dvou skupin větší než u poslední skupiny. Pravděpodobnost výskytu první a třetí skupiny - tedy lidí orientovaných na práci - se však v české společnosti mezi lety 1991 až 2008 zmenšuje. Roste naopak druhá skupina, orientovaná především na prátele a volný čas.

Latentní shlukovou analýzu jsme rovněž použili pro identifikaci skupin př́tomných na českém trhu práce $\mathrm{z}$ hlediska vnímání konceptu práce. I v tomto př́ípadě jsme rozlišili tř̌i skupiny. První a největší skupina chápe práci především z hlediska platu a možností využít své schopnosti (kombinace materiálního a seberealizačního aspektu práce). Míra vnímání tohoto pojetí práce byla v roce 1991 a v roce 2008 v české společnosti totožná. Respondenti s takovým chápáním práce jsou především středoškolského vzdělání. Druhá skupina se orientuje pouze na materiální/instrumentální aspekty práce (dobrý plat a jistotu, že nepřijdou o místo). Velikost této skupiny v čase mírně roste a tvoří ji respondenti s nejnižším vzděláním (vyučení). Třetí, nejmenší skupina se orientuje na sociální a seberealizační aspekty práce 
(zodpovědná a užitečná práce, včetně využití individuálních schopností v práci). V čase tato skupina mizí. V roce 2008 byla jen velmi malá pravděpodobnost jejího výskytu v české společnosti. Tuto skupinu tvoří lidé s nejvyšším vzděláním.

\section{Literatura}

ARDICHVILI, Alexandre ; KUCHINKE, Peter K. International Perspectives on the Meanings of Work and Working : Current Research and Theory. Advances in Developing Human Resources, 2009, roč. 11, č. 2, s. 155 - 167. ISSN 1523-4223.

ARONOWITZ, Stanley; DiFAZIO, William. The Jobless Future. Minneapolis : University of Minnesota Press. 1994. 377 s. ISBN 0-816-62193-4.

BAUMAN, Zygmunt. Úvahy o postmoderni době. 1. vyd. Praha : Slon, 1995. 163 s. ISBN 80-8585-012-5.

BAUMAN, Zygmunt. Work, Consumerism and the New Poor. 1. vyd. Buckingham : Open University Press, 1998. 106 s. ISBN 0-335-20155-5.

BAUMAN, Zygmunt. Tekutá modernita. 1. vyd. Praha: Mladá fronta, 2002. 343 s. ISBN 80-2040-966-1.

BECK, Ulrich. Democracy without Enemies. 1. vyd. Cambridge : Polity Press. 1998. 189 s. ISBN 0-745-61823-5.

BECK, Ulrich. The Brave New World of Work. 1. vyd. Cambridge : Polity Press. 2000. 202 s. ISBN 0-745-62397-2.

BECK, Ulrich. Riziková společnost. Na cestě k jiné modernitě. 1. vyd. Praha : Slon. 2004. 431 s. ISBN 80-8642-932-6.

BECK, Ulrich. Nezaměstnanost není selhání. Respekt, 2006, roč. 17, č. 46, s. 8. ISSN 0862-6545.

BELL, Daniel. Kulturni rozpory kapitalismu. 1. vyd. Praha : Slon, 1999. 335 s. ISBN 80-8585-084-2.

BOURDIEU, Pierre. Teorie jednání. 1. vyd. Praha : Karolinum, 1998. 179 s. ISBN 80-7184-518-3.

CARLSON, Dawn S. ; GRZYWACZ, Joseph G. ; ZIVNUSKA, Suzanne. Is work-family balance more than conflict and enrichment? Human Relations, 2009, roč. 62, č. 10, s. 1459 - 1486. ISSN 0018-7267.

CASEY, Catherine. Work, Self and Society : After Industrialism. 1. vyd. New York and London : Routledge. 1995. 256 s. ISBN 0-41511-203-6.

CASEY, Catherine. Work, Non-Work and Resacralizing Self. Social Compass, 2000, roč. 47, č. 4, s. 571 - 587. ISSN 0037-7686.

CASTEL, Robert. From Manual Workers, to Wage Labourers : Transformation of the Social Questio. New Brunswick : Transaction, 2003. 437 s. ISBN 0-765-80149-3.

CLOGG, Clifford C. New Developments in Latent Structure Analysis. In JACKSON, D.J., BORGATTA, E.F. Factor Analysis and Measurement in Sociological Research. Beverly Hills: Sage, 1981, s. 215 - 246. ISBN 0-803-99814-7.

CLOGG, Clifford C. Latent class models. In ARMINGER, G., CLOGG, C.C., SOBEL, M.E. (eds.) Handbook of Statistical Modeling for the Social and Behavioral Sciencesy. New York : Plenum, 1995, s. 311 - 359. ISBN 0-306-44805-X.

DAHRENDORF, Ralf. Úvahy o revoluci v Evropě. 1. vyd. Praha : Nakladatelství Evropského kulturního klubu, 1991a. 157 s. ISBN 80-8521-217-X.

DAHRENDORf, Ralf. Moderný sociálny konflikt. Bratislava : Archa, 1991b. 320 s. ISBN 80-7115-024-X.

DAVOINE, Lucie ; MÉDA, Dominique. Work More to Earn More? The Mixed Feelings of Europeans. International Labour Review, 2009, roč. 148, č. 1-2, s. 15 - 46. ISSN 1564-913X.

DELORS, Jacques. Our Europe : The Community and National Development. London and New York : Verso, 1992. ISBN 0-860-91380-5. 
DEKKER, Paul. Diverse Europe. Public opinion on the European Union \& Cultural diversity, economics and policy. European Outlook 4, Annex to the State of the European Union 2007.

DERANTY, Jean-Phillippe. Work and the Precarisation of Existence. European Journal of Social Theory, 2008, roč. 11, č. 4, s. 443 - 463. ISSN 1368-4310.

De WITTE, H. ; HALMAN, L. ; GELISSEN, J. European work orientations at the end of the twentieth century. In ARTS, W., HALMAN, L. (eds.) European Values at the Turn of the Millennium. LeidenBoston : Brill Academic Publisher, 2004, s. 255 - 276. ISBN [European Values Studies Series, Volume 7]. ISBN 90-04-13981-8.

FOUCAULT, Michel. Dohližet a trestat. Praha : Dauphin, 2000. 427 s. ISBN 80-860-1996-9.

FOURASTIÉ, Jean. 40000 hodin. Praha : Mladá fronta, 1969. 213 s.

FRONE, Michael R. Work-Family Balance. In QUCK, J.C., TETRICK, L.E. Handbook of occupational health psychology. 1. vyd. Washington: American Psychological Association, 2003, s. 143 - 162. ISBN 1-557-98927-3.

GIDDENS, Anthony. Beyond Left and Right. The Future of Radical Politics. 1. vyd. Cambridge : Polity Press, 1994. 276 s. ISBN 0-745-61439-6.

GOLDTHROPE, John H. ; LOCKWOOD, David ; BECHHOFER, Frank ; PLATT, Jennifer. The Affluent Worker : Industrial Attitudes and Behaviour. London : Cambridge University Press, 1968. 206 s. ISBN 0-521-09466-6.

GOODMAN, Leo A. Exploratory Latent Structure Analysis Using Both Identifi able and Unidentifi able Models. Biometrica, 1974, roč. 61, s. 215 -231. ISSN 0006-3444.

GORZ, André. Reclaiming Work. Beyond the Wage-Based Society. 1 .vyd. Cambridge : Polity Press, 1999. 185 s. ISBN 0-745-62127-9.

GREENHAUS, Jefferey H. ; BEUTELL, Nicholas J. Sources of Conflict between Work and Family Roles. Academy of Management Review, 1985, roč. 10, č. 1, s. 76 - 88. ISSN 0363-7425.

HAGENAARS, Jacques A. Loglinear Models with Latent variables. London : Sage, 1993. 75 s. ISBN 0-803-94310-5.

HAGENAARS, Jacques A. ; McCutcheon, Allan. (eds.) Applied Latent Class Analysis. Cambridge : Cambridge University Press, 2002. 454 s. ISBN 0-521-59451-0.

HAGENAARS, Jacques A. ; HALMAN, Loek ; MOORS, Guy. Exploring Europe's Basic Value Map. In ARTS, W., HAGENAARS, J., HALMAN, L. The Cultural Diversity of European Unity. Findings, Explanations and Reflections from European Value Study. Leiden : Brill. 2003, s. 25 - 58. ISBN 9-004-12299-0.

HALMAN, Loek. Individualization and Fragmentation of Work Values. Evidence from the European Values Studies. Tilburg: WORC-Work and Organization Research Centre, 1996.

HALMAN, Loek ; MÜLLER, Hans. Contemporary Work Values in Africa and Europe. Comparing Orientations to Work in African and European Societies. International Journal of Comparative Sociology, 2006, roč. 47, č. 2, s. 117 - 143. ISSN 0020-7152.

HALMAN, Loek, LUIJKX, Ruud ; van ZUNDERT, Marga. (eds.) Atlas of European Values. Leiden : Brill Academic Publisher, 2005. 139 s. ISBN 9-004-14460-9.

HARPAZ, Itzhak. The Transformation of Work Values in Israel : Stability and Change Over Time. Monthly Labor Review, 1999, roč. 122, č. 5, s. 46 - 50. ISSN 0098-1818.

HARPAZ, Itzhak ; Fu, Xuanning. The Structure of the Meaning of Work : A Realative Stability Amidst Change. Human Relations, 2002, roč. 55, č. 6, s. 639 - 668. ISSN 0018-7267.

ILLICH, Ivan. Odškolněni společnosti. 1. vyd. Praha : Slon, 2001.109 s. ISBN 80-8585-096-6.

INGLEHART, Ronald. The Silent Revolution. Princeton : Princeton University Press, 1977. ISBN 0-691-10038-1.

INGLEHART, Ronald. Modernization and Postmodernization : Cultural, Economic, and Political Change. Princeton : Princeton University Press, 1997. 453 s. ISBN 0-691-01181-8. 
INGLEHART, Ronald. Globalisation and Postmodern Values. The Washington Quarterly, 1999, roč. 23, č. 1, s. 215 - 228. ISSN 0163-660X.

INGLEHART, Ronald; WELZEL Christian. Modernization, Cultural Change and Democracy [online]. New York : Cambridge University Press, 2005. Cultural Map of the World (based on the World Values Surveys). [cit. 2010-15-10]. Dostupné na www: <http://www.worldvaluessurvey.org/wvs/ articles/folder_published/article_base_54>.

INGLEHART, Ronald. Changing Values among Western Publics from 1970 to 2006. West European Politics, 2008, roč. 31, č. 1-2, s. 130 - 146. ISSN 0140-2382.

JAUFMANN, Dieter. Fehlzeiten, Einstellungen zur Erwerbsarbeit und Belastungen. Die Entwicklung in der Bundesrepublik Deutschland. In JAUFMANN, D., PFAFF, M. (eds.) Die neue Arbeitsmoral. Industrieländer im internationalen Vergleich. Frankfurt am Main : Campus, 2000, s. 33 - 114. ISBN 3-593-36319-4.

KEYNES, John M. Economic Possibilities for our Grandchildren. In Keynes, J.M. Essays in Persuasion. New York : W.W. Norton \& Co. [původně Keynes J. M. Economic Possibilities for our Grandchildren. In Keynes, J.M. Essays in Persuasion. London : Macmillan, 1931]. 1963, s. 358 - 373.

KLEINBAUM, David G. ; KLEIN, Mitchel. Logistic Regression : A Self-Learning Text. New York : Springer, 2002. 520 s. ISBN 0-387-95397-3.

LASH, Scott ; URRY, John. The End of Organized Capitalism. Cambridge : Polity Press, 1987. 383 s. ISBN 0-299-11670-0.

LAZARSFELD, Paul F. ; HENRY, Neil W. Latent Structure Analysis. Boston : Houghton Mifflin, 1968. $294 \mathrm{~s}$

LINCOLN, James R. ; KALLEBERG, Arne L. Culture, Control, and Commitment. 1. vyd. Cambridge : Cambridge University Press, 1990. 291 s. ISBN 0-521-36517-1.

MAGIDSON, Jay ; VERMUNT, Jeroen K. Latent Class Models. In KAPLAN, D. (ed.) The Sage Handbook of Quantitative Methodology for the Social Sciences. Thousand Oaks : Sage, 2004, s. 175 198. ISBN 0-7619-2359-4.

MANNHEIM, Bilha; BARUCH, Yehuda ; TAL, Joseph. Alternative Models for Antecedents and Outcomes of Work Centrality and Job Satisfaction of High Tech Personnel. Human Relations, 1997, roč. 50, č. 12, s. $1537-1562$. ISSN 0018-7267.

MAREŠ, Petr ; BÁNOVCOVÁ, Lenka. Spokojenost s prací -stav vnitřních dimenzí 1967-2002. Sociální studia, 2002, č. 8, s. 39 - 52. ISSN 1214-813X.

MAREŠ, Petr. The Czechs : Jobs and Work. Czech Sociological Review, 2001, roč. 9, č. 1, s. 69 - 84. ISSN 1210-3861.

MAREŠ, Petr. Zaměstnání, rodina a dítě v dynamice moderní společnosti. In SIROVÁTKA, T. (ed.) Rodina, zaměstnání a sociální politika, 1. vyd. Brno : Albert, 2006, s. 19 - 54. ISBN 80-7326-104-9.

McCULLAGH, Peter ; NELDER, John A. Generalized Linear Models. 2. vyd. London : Chapmann \& Hall/CRC, 1999. 511 s. ISBN 0-41231-760-5.

MOW - International Research Team. The Meaning of Working. London : Academic Press, 1987.

MOŽNÝ, Ivo. Význam sféry práce pro vytváření socialistického způsobu života. In Studia minora facultatis Philosophicae Universitatis Brunensis, G18. Brno : Universita J. E. Purkyně, 1974, s. 41 - 52.

POWERS, Daniels A. ; XIE, Yu. Statistical Methods for Categorical Data Analysis. 1. vyd. New York : Academic Press, 2000. 324 s. ISBN 0-12563-736-5.

RAFFE, D. Young People not in Education, Employment or Training. CES : University of Edinburgh, 2003. $27 \mathrm{~s}$.

RIFKIN, Jeremy. The End of Work. The Decline of the global Labor Force and the dawn of the PostMarket Era. New York : Putman, 1995. s. ISBN 0-87477-779-8.

RUIZ-QUINTANILLA, Antonio S. ; WILPERT, Bernhard. Are Work Meanings Changing? European Work and Organizational Psychologist, 1991, roč. 1, č. 1, s. 91 - 109. 
SENNETT, Richard. The Corrosion of Character. The personal consequences of work in the new capitalism. 1. vyd. New York : Norton, 1998. 176 s. ISBN 0-39304-678-8.

SENNETT, Richard. The Culture of the New Capitalism. 1. vyd. New Haven : Yale University Press, 2006. 224 s. ISBN 0-30011-992-5.

SHARABI, Moshe; HARPAZ, Itzhak. Core and Peripheral Values : An Over Time Analysis of Work Values in Israel. Journal of Human Values, 2009, roč. 15, č. 2, s. 153 - 166. ISSN 0971-6858.

SIROVÁTKA, Tomáš. Rodina a reprodukce versus zaměstnání a role sociální politiky. In SIROVÁTKA, T. (ed.) Rodina, zaměstnání a sociální politika. 1. vyd. Brno : Albert, 2006, s. 19 - 54. ISBN 80-7326-104-9.

SWEET, Stephen ; MEIKSINS, Peter. Changing Contours of Work : Jobs and opportunities in the new economy. Thousand Oaks, CA : Pine Forge Press, 2008. 264 s. ISBN 1-41291-744-1.

TARNAI, Christina ; GRIMM, Holger ; WATERMANN, Rainer. Work Values in European Comparison : School Education and Work Orientation in Nine Countries. Tertium Comparationis. Journal für Internationale Bildungsforschung, 1995, č. 1, s. 139 - 163.

VALENTOVÁ, Marie. Postoje k opatřením týkajícím se rodiny a rovnováhy pracovního a rodinného života /mezinárodní srovnání). In SIROVÁTKA, T. (ed.) Rodina, zaměstnání a sociální politika. Brno : Albert, 2006, s. 165 - 202. ISBN 80-7326-104-9.

VEČERNÍK, Jiří. Work Values and Job Attitudes in the Czech Republic between 1997 and 2005. Sociologický časopis, 2006, roč. 42, č. 6, s. 1219 - 1240. ISSN 0038-0288.

VERMUNT, Jeroen K. Log-linear models for event histories. Thousand Oakes : Sage, 1997. 360 s. ISBN 0-76190-937-0.

VERMUNT, Jeroen K. ; MAGIDSON, Jay. Latent GOLD 4.0 : Users Guide. Belmont : Statistical Innovations, 2005.

VOYDANOFF, Patricia. Toward a Conceptualization of Perceived Work-Family Fit and Balance : A Demands and Resources Approach. Journal of Marriage and Family, 2005, roč. 67, č. 4, s. 822 - 836. ISSN 0022-2445.

WATSON, Tony J. Work and the Sociological Imagination : The Need for Continuity and Change in the Study of Continuity and Change. Sociology, 2009, roč. 43, č. 5, s. $861-877$. ISSN 0038-0385.

ZANDERS, Harry. Changing Work Values. In de MOOR, R. (ed.) Values in Western Societies. Tilburg : Tilburg University Press, 1995, s. 129 - 154. ISBN 90-361-9636-1.

\section{Autoři}

Petr Mareš je profesorem na Fakultě sociálních studii Masarykovy univerzity. Zabývá se především sociálními problémy, nerovností, chudobou, nezaměstnaností.

Kontakt: pmares@fss.muni.cz

Tomáš Katrňák je docentem na Fakultě sociálních studii Masarykovy univerzity. Zabývá se sociální stratifikaci, třídní analýzou, sociální a vzdělanostní mobilitou, sociální statistikou a metodami zpracování sociologických dat.

Kontakt: katrnak@fss.muni.cz 